Jurnal of Education Technologi and Innovation (JETI)

Volume 01 No 2 Desember 2018

doi. https://doi.org/10.31537/jeti.v1i2

p-ISSN : 262-2080

e-ISSN: $2621-2137$

\title{
PENGARUH PENGGUNAAN MEDIA PEMBELAJARAN BERBASIS POWERPOINT DAN BUKU TEKS TERHADAP HASIL BELAJAR ILMU PENGETAHUAN ALAM (IPA) MATERI TATA SURYA SISWA KELAS VI SEMESTER GANJIL TAHUN PELAJARAN
}

\author{
2018-2019 DI MI NEGERI 2 JEMBER
}

\author{
Eko Iswanto', Rudy Sumiharsono’, Syamsul Hidayat \\ PASCA SARJANA IKIP PGRI JEMBER \\ ekoiswanto101069@gmail.com
}

\begin{abstract}
Through the use of a textbook-based learning media as the main reference and interesting point-based learning media, learning becomes fun, not boring, full of motivation, enthusiasm, attracting attention and responding to a problem faced can be resolved so that learning objectives are achieved. The learning conditions allow student learning outcomes to increase, especially science learning outcomes.

Based on the description of the background, the problems studied were formulated as follows: a) How much influence the use of power point based learning media on improving student learning outcomes ?, b) How much influence does the use of text-based learning media on improving student learning outcomes? c) How much influence simultaneously the use of power point-based learning media and textbooks on improving student learning outcomes?

This type of research is quantitative research with survey methods. As for the population and at the same time the sample in this study were all students of class VI MI Negeri 2 Jember, amounting to 50 people. Data collection techniques by distributing questionnaires / questionnaires with a Likert scale. Data analysis used simple correlation and multiple correlation techniques with the help of computers using the SPSS 13 program.

The results of this study also show; (1) there is a significant influence between the use of power point-based learning media to improve student learning outcomes. The correlation coefficient value of 0.863 shows the level of closeness between these two variables is very strong, (2) there is an effect of the use of textbook-based learning media to improve student learning outcomes, the result is the correlation coefficient is 0.893 . The correlation coefficient of 0.893 shows the level of closeness between the two variables is very strong (3) there is an influence between the use of power point-based learning media and textbooks on improving student learning outcomes. Simultaneously the use of power point-based learning media and textbooks on improving student learning outcomes has a correlation coefficient $(\mathrm{R})$ of 0.934 , indicating the level of closeness between the three variables is very strong, while the magnitude of the influence of the two learning media on student learning outcomes is $87.23 \%$. The influence is quite large and significant.
\end{abstract}

In conclusion, the use of power point based learning media, at MIN 2 Jember, based on the results of the study has a tendency to belong to the category of both improving student learning outcomes. This can be seen from the results of research using power point-based learning media which consists of all dimensions having an average of $79.74 \%$. As for the use of textbook-based learning media, for all dimensions it has an average of $70.67 \%$. Most students can achieve learning outcomes from all levels of ability, namely for the competency dimension remembering $75.64 \%$ 
(good category), understanding competency dimensions of $76.20 \%$ (good category), applying competency dimensions of $76 \%$ (good category), the dimensions of analyzing competency were

$72.5 \%$ (good category), the dimensions of competency were evaluated at $62.04 \%$ (good category), while for the dimensions of competency creating was $70.8 \%$ (good category).

Based on the above conclusions, it is suggested to: 1) The principal must facilitate the means of supporting learning media to achieve learning objectives, 2) Science teachers should try to improve student learning outcomes optimally through the use of instructional media, so as to improve the quality of the learning process and education quality , 3) The next researcher, can conduct research by developing learning media that are more up to date so as to more motivate

student learning in order to achieve more optimal learning outcomes.Keywords:powerpoint,textbook,studentlearningoutcomes 


\begin{abstract}
ABSTRAK
Melalui penggunaan sebuah media pembelajaran berbasis buku teks sebagai referensi utama dan media pembelajaran yang berbasis power point yang menarik, belajar menjadi menyenangkan, tidak membosankan, penuh motivasi, semangat, menarik perhatian dan menanggapi suatu permasalahan yang dihadapi dapat diselesaikan dengan baik sehingga tercapai tujuan pembelajaran. Kondisi belajar tersebut memungkinkan hasil belajar siswa menjadi meningkat, khususnya hasil belajar IPA.

Berdasarkan uraian latar belakang, masalah yang diteliti dirumuskan sebagai berikut: a) Seberapa besar pengaruh penggunaan media pembelajaran berbasis power point terhadap peningkatan hasil belajar siswa?, b) Seberapa besar pengaruh penggunaan media pembelajaran berbasis buku teks terhadap peningkatan hasil belajar siswa? c) Seberapa besar pengaruh secara bersamaan penggunaan media pembelajaran berbasis power point dan buku teks terhadap peningkatan hasil belajar siswa?.

Jenis penelitian ini adalah Penelitian kuantitatif dengan metode survey. Adapun yang menjadi populasi dan sekaligus sampel dalam penelitian ini adalah seluruh siswa kelas VI MI Negeri 2

Jember yang berjumlah 50 orang. Teknik pengumpulan data dengan cara pembagian angket/kuesioner dengan skala Likert. Analisis data menggunakan rumus teknik korelasi sederhana dan korelasi ganda dengan bantuan komputer dengan program SPSS 13.

Hasil penelitian ini juga menunjukan; (1) terdapat pengaruh yang signifikan antara penggunaan media pembelajaran berbasis power point terhadap peningkatan hasil belajar siswa. Nilai koefisien korelasi sebesar 0,863 menunjukan tingkat keeratan antara dua variabel tersebut adalah sangat kuat, (2) ada pengaruhnya penggunaan media pembelajaran berbasis buku teks terhadap peningkatan hasil belajar siswa, hasilnya koefisien korelasi adalah 0.893 . Nilai koefisien korelasi sebesar 0.893 menunjukan tingkat keeratan antara dua variabel tersebut adalah sangat kuat (3) ada pengaruh antara penggunaan media pembelajaran berbasis power point dan buku teks terhadap peningkatan hasil belajar siswa. Secara bersamaan penggunaan media pembelajaran berbasis power point dan buku teks terhadap peningkatan hasil belajar siswa memiliki koefisien korelasi (R) 0,934, menunjukan tingkat keeratan antara ketiga variabel tersebut sangat kuat, sedangkan besarnya pengaruh kedua media pembelajaran tersebut terhadap hasil belajar siswa adalah sebesar $87,23 \%$. Pengaruhnya cukup besar dan signifikan.
\end{abstract}

Katakunci:powerpoint,bukuteks, hasilbelajarsiswa

\title{
1. PENDAHULUAN
}

Pada hakikatnya proses belajar mengajar itu merupakan proses komunikasi antara guru dan siswa, pada prakteknya mentransfer pengetahuan, pengalaman, dan gagasan (ide) guru ke siswa atau dari siswa ke siswa yang lain itu tidaklah mudah. Ketidaklancaran komunikasi membawa akibat terhadap pesan yang diberikan guru. Beberapa ahli memberikan definisi tentang media pembelajaran. Menurut Arif S. Sadiman dkk (2007: 6) media adalah segala sesuatu yang dapat menyalurkan pesan dari pengirim kepada penerima sehingga dapat merangsang pikiran, perasaan dan minat serta perhatian siswa sedemikian rupa sehingga proses belajar terjadi.

Seiring perkembangan jaman, munculnya teknologi yang sangat pesat saat ini membuat revolusi yang besar terhadap dunia, semua pekerjaan terasa mudah dan murah. Demikian pula dalam pendidikan yang berkaitan dengan Proses Belajar Mengajar (PBM) di sekolah harus menggunakan beberapa variasi media pembelajaran yang digunakan untuk mengajarkan ilmu kepada anak didik yang semakin maju dan canggih, yang bertujuan untuk meningkatkan hasil belajar, pembelajaran lebih menarik, 
dan peserta didik dapat lebih lama dalam mengingat pesan yang diterima, lebih termotivasi dalam belajar.

Peraturan Pemerintah Republik Indonesia Nomor 19 tahun 2005, tentang standar nasional pendidikan, pada BAB VII (sarana dan prasarana), pasal 42, Butir 1 : “ setiap satuan pendidikan wajib memiliki sarana yang meliputi perabot, peralatan pendidikan, media pendidikan, buku dan sumber belajar lainnya, bahan habis pakai, serta perlengkapan lain yang diperlukan untuk menunjang proses pembelajaran yang teratur dan berkelanjutan". Peraturan ini menunjukkan media pendidikan merupakan salah satu sarana yang diperlukan untuk menunjang proses pembelajaran.

Media pembelajaran pada hakekatnya merupakan salah satu komponen sistem pembelajaran (Asri, 2008: 3). Tanpa media, komunikasi tidak akan terjadi dan proses pembelajaran sebagai proses komunikasi juga tidak akan bisa berlangsung secara optimal (I Wayan, 2011:3). Penggunaan media dalam pembelajaran dapat membantu anak dalam memberikan pengalaman yang bermakna bagi siswa dan mempermudah siswa dalam memahami sesuatu yang abstrak menjadi lebih konkrit.

Beberapa peneliti telah mengkaji media pembelajaran (Elaine, et all, 2014; Abiodun, et all, 2015; Alaa Sadik, 2012). Elaine (2014) mengeksplorasi hubungan antara keberhasilan siswa dalam memperoleh literasi perangkat lunak powerpoint dan keterlibatan siswa yang lebih luas dan dalam pemahaman pengetahuan di setiap disiplin ilmu. Abiodun (2015) mengungkapkan bahwa perolehan keterampilan yang relevan di multi media akan meningkatkan pengajaran dan pembelajaran konsep-konsep ilmiah di sekolah menengah di Logos Nigeria.Berdasarkan temuannya, Abiodun (2015) merekomendasikan untuk menanamkan pengetahuan keterampilan multi media dalam meningkatkan pengajaran sains. Hasil penelitian Alaa Sadik (2012) menunjukkan bahwa anak- anak menyukai presentasi video yang disiapkan oleh guru mereka berguna untuk pengembangan literasi anak-anak mereka. Perangkat lunak video ini memperoleh konten media dari berbagai sumber dan perangkat, termasuk webcam, mikrofon, slide PowerPoint, papan gambar, dan papan ketik dengan cara yang disederhanakan.

Salah satu jenis media yang sedang berkembang adalah media berbasis komputer, salah satu contohnya adalah media pembelajaran berbasis powerpoint. Munadi dkk (2010:150) mengungkap bahwa kelebihan media pembelajaran berbasis powerpoint mampu menggabungkan semua unsur media, seperti: teks, gambar, video, animasi dan sound. Sehingga media power point tidak hanya bersifat verbalitas belaka. Dengan media ini pula, peserta didik akan merasa bahwa mereka seolah-olah terlibat di dalam kegiatan itu sendiri, sehingga motivasi dan minat belajar akan timbul lebih besar lagi. Menurut Edgar Dale yang bukunya dikutip oleh Sardiman (2002:8) bahwa pengalaman belajar seseorang 75\% diperoleh dari indera penglihatan (mata), $13 \%$ melalui indera pendengaran (telinga) dan selebihnya melalui indera yang lain.

Media pembelajaran berbasis power point dapat memanfaatkan waktu yang lebih banyak untuk berkomunikasi, berdiskusi, ataupun 
bertanya kepada pengajar(guru). Dengan media pembelajaran yang menarik, belajar menjadi menyenangkan, tidak membosankan, penuh motivasi, semangat, menarik perhatian dan menanggapi suatu permasalahan yang dihadapi dapat diselesaikan dengan baik. Kondisi belajar tersebut memungkinkan hasil belajar siswa meningkat.

Menurut Susilana dkk (2007: 99) media power point merupakan program aplikasi persentasi dalam komputer. Sedangkan media power point dalam pembelajaran dapat diartikan sebagai aplikasi multimedia yang digunakan dalam proses pembelajran, dengan kata lain untuk menyalurkan pesan (pengetahuan, keterampilan dan sikap) serta dapat merangsang pikiran, perasaan, perhatian dan kemauan belajar sehingga secara sengaja proses belajar terjadi, bertujuan dan terkendali.

Guna memenuhi tuntutan perkembangan jaman, Menteri Pendidikan dan Kebudayaan mengesahkan Kurikulum 2013 sebagai pembaharuan dari Kurikulum

2006. Titik berat Kurikulum 2013 adalah bertujuan agar peserta didik memiliki kemampuan yang baik dalam melakukan observasi, bertanya, bernalar, dan mengkomunikasikan (mempresentasikan). Pada intinya, orientasi pengembangan Kurikulum 2013 adalah tercapainya kompetensi yang berimbang antara sikap, keterampilan, dan pengetahuan, di samping cara pembelajarannya yang holistik dan menyenangkan.

Untuk memenuhi tuntutan tersebut, dilakukan langkah penguatan tata kelola dengan cara menyiapkan beberapa hal seperti; (1) menyiapkan buku pegangan pembelajaran yang terdiri dari buku siswa dan buku guru, (2) menyiapkan guru supaya memahami pendayahgunaan sumber belajar yang telah disiapkan dan sumber lain yang dapat mereka manfaatkan (3) memperkuat peran pendampingan dan pemantauan oleh pusat dan daerah dalam pelaksanaan pembelajaran.

Untuk memenuhi tuntutan tersebut, dilakukan langkah penguatan tata kelola dengan cara menyiapkan beberapa hal seperti; (1) menyiapkan buku pegangan pembelajaran yang terdiri dari buku siswa dan buku guru, (2) menyiapkan guru supaya memahami pendayahgunaan sumber belajar yang telah disiapkan dan sumber lain yang dapat mereka manfaatkan (3) memperkuat peran pendampingan dan pemantauan oleh pusat dan daerah dalam pelaksanaan pembelajaran.

Sehubungan dengan penyiapan buku dalam Kurikulum 2013 ini, pemerintah secara langsung menyusun buku tersebut. Buku Teks Pelajaran dan Buku Panduan Guru atau biasa disebut juga Buku Siswa dan Buku Guru tersebut dalam proses penyusunannya dilakukan langsung oleh pemerintah sebagai upaya meminimalisir kesalahan Buku Teks Pelajaran kurikulum sebelumnya.

Meski pemerintah telah meminimalisir persoalan dengan mengatur Buku Teks Pelajaran tersebut, pelaksanaan Kurikulum 2013 masih dibayangi sejumlah persoalan terutama persoalan yang berkaitan dengan kesiapan sarana-prasarana (sarpras) pendukung, maupun tenaga pengajar, juga mempengaruhi pola mengajar, terlebih adanya anjuran Buku Teks Pelajaran yang akan dipakai dalam proses implementasi Kurikulum 2013. Sehingga, proses implementasi Kurikulum 2013 dititikberatkan pada peranan guru pengampu dalam hal ini guru pengampu mata pelajaran IPA untuk memanfaatkan buku teks sebagai media pembelajaran yang dapat mendampingi media pembelajaran lainnya seperti media pembelajaran powerpoint.

Namun tingkat efektivitas pemakaian buku teks tersebut dipengaruhi berbagai macam faktor, terlebih dengan beragam kondisi di masing-masing sekolah belum mampu. Hal ini tentu menjadi penegasan masalah penelitian ini terlebih dengan tingkat sekolah yang dapat dikategorikan mampu. 
Buku teks merupakan buku acuan mata pelajaran tertentu yang digunakan siswa atau pendidik guna memperlancar kegiatan belajar mengajar. Keberadaan buku teks memang sangat membantu proses pembelajaran. Dengan adanya buku teks, siswa dapat belajar tanpa adanya seorang guru, karena buku bersifat permanen, dan bisa dibaca kapan pun. Uraian-uraian atau penjelasan-penjelasan singkat mengenai materi-materi tertentu dalam buku teks sangat membantu pemahaman awal siswa terhadap mata pelajaran. Buku teks juga dapat mentransformasikan ilmu pengetahuan dan ilmu kehidupan dengan kompetensi dasar yang diajarkan.

Fenomena yang ada di lapangan khususnya MIN 2 Jember belum memanfaatkan secara maksimal media pembelajaran berbasis powerpoint dan juga penggunaan buku teks belum efektif sebagai media pembelajaran. Di sekolah ini, umumnya para guru hanya menggunakan media konvensional (ceramah dan pemberian tugas), serta masih menggunakan media-media sederhana seperti : gambar, wallchart, whiteboard dan sebagainya, yang dengan media ini tentunya kurang menarik belum mampu maksimal membantu siswa dalam belajar mengajar. Di sekolah ini masih ada beberapa guru yang menggunakan hanya terbatas pada media LKS yang ditulis oleh penulis dengan tidak semua konten mengacu pada tuntutan kurikulum yang berlaku saat ini.

Melalui sebuah media pembelajaran berbasis buku teks sebagai referensi utama dan media pembelajaran yang berbasis power point yang menarik, belajar menjadi menyenangkan, tidak membosankan, penuh motivasi, semangat, menarik perhatian dan menanggapi suatu permasalahan yang dihadapi dapat diselesaikan dengan baik sehingga tercapai tujuan pembelajaran. Kondisi belajar tersebut memungkinkan hasil belajar siswa menjadi meningkat, khususnya hasil.

Berdasarkan uraian latar belakang tersebut, maka penelitian ini mengangkat judul "Pengaruh Penggunaan Media Pembelajaran berbasis Power Point dan Buku teks Terhadap Hasil Belajar Ilmu Pengetahuan Alam (IPA) Materi Tata Surya Siswa Kelas VI Semester Ganjil Tahun Pelajaran 2018-2019 di MI Negeri 2 Jember '.

\section{METODE}

Jenis penelitian dalam penulisan tesis ini adalah Penelitian kuantitatif dengan metode survei. Data dan informasi dalam penelitian dikumpulkan dari responden dengan menggunakan kuesioner. Setelah data diperoleh kemudian hasilnya akan dipaparkan secara deskriptif dan akhir penelitian akan dianalisis untuk menguji hipotesis yang diajukan pada awal penelitian.

Menurut tingkat eksplanasinya, penelitian ini merupakan penelitian asosiatif (pengaruh) yang bersifat pengaruh sebab akibat (kausal), dimana variabel bebas mempengaruhi variabel terikat secara langsung. Menurut jenis data dan analisisnya, penelitian ini menggunakan mix-method analisis, yaitu gabungan antara kuantitatif dengan kualitatif, dimana analisis utamanya lebih difokuskan kepada analisis kuantitatif, sedangkan analisis kualitatif sebagai pelengkap.

Dalam penelitian ini terdapat dua variabel bebas, yaitu, variable X1 (penggunaan media pembelajaran berbasis powerpoint) dan variabel X2 (penggunaan media pembelajaran berbasis buku teks), serta satu variabel terikat yaitu Hasil belajar siswa (Y). Kedua variabel bebas $\left(\mathrm{X}_{1}\right.$ dan $\left.\mathrm{X}_{2}\right)$ dihubungkan dengan variabel terikat $(\mathrm{Y})$. Dalam 
penelitian ini akan dicari pola pengaruh (1) Pengaruh antara variabel $\mathrm{X}_{1}$ dengan variabel $\mathrm{Y}$, (2) Pengaruh antara variabel $\mathrm{X}_{2}$ dengan variabel $\mathrm{Y}$, dan (3) Pengaruh antara variabel $\mathrm{X}_{1}$ dan $\mathrm{X}_{2}$ secara bersama- sama dengan variabel $\mathrm{Y}$.

Adapun yang menjadi populasi dalam penelitian ini adalah seluruh siswa MI Negeri 02 Jember berjumlah 50 orang yang sekaligus sebagai sampel dalam penelitian ini. Dengan demikian penelitian ini disebut dengan penelitian populasi.

Dalam penelitian ini, untuk mengumpulkan data peneliti menggunakan teknik pengumpulan data dengan cara pembagian angket/kuesioner dengan skala Likert dan melakukan post tes. Angket dibagikan kepada seluruh siswa yang menjadi sampel penelitian. Angket dibagikan untuk memperoleh data tentang variabel penggunaan media pembelajaran berbasis powerpoint dan variabel penggunaan media pembelajaran berbasis. Seangkan post test dilakukan untuk memperoleh data variabel hasil belajar siswa. Angket tersebut diambil kembali setelah diisi oleh responden. Tujuan digunakannya teknik pengumpulan data adalah untuk mendapatkan data yang selanjutnya dipergunakan untuk menguji dan membuktikan hipotesa.

Selanjutnya dilakukan analisis data untuk menentukan pengaruh variabel penggunaan media pembelajaran berbasis powerpoint, variabel penggunaan media pembelajaran berbasis buku teks, serta variabel hasil belajar siswa dengan menggunakan teknik korelasi Ganda dengan bantuan program komputer dengan SPSS 13.

\section{HASIL}

Terdapat pengaruh yang signifikan antara penggunaan media pembelajaran berbasis powerpoint dengan hasil belajar siswa. Ini dibuktikan angka koefisien product moment sebesar 0,863, sedangkan t-hitung 11,861 lebih besar dari t-tabel yaitu 2,000. Nilai koefisein 0,863 menunjukan tingkat keeratan antara dua variabel tersebut sangat kuat. Besarnya koefisien korelasi penggunaan media pembelajaran berbasis powerpoint dengan hasil belajar siswa adalah sebesar 0,863 dan koefisien determinasinya 74,5\%. Artinya bahwa pengaruh penggunaan media pembelajaran berbasis powerpoint dengan hasil belajar siswa sangat signifikan. Dan hasil belajar siswa dipengaruhi oleh penggunaan media pembelajaran berbasis powerpoint sebesar 74,5\%, sedangkan sisanya $25,5 \%$ merupakan faktor lain, misalnya metode mengajar guru, motivasi siswa atau kompetensi siswa lainnya.

Sedangkan koefisien product moment sebesar 0,893, sedangkan t-hitung 13,783 lebih besar dari t-tabel yaitu 2,000, maka berdasarkan kriteria uji, dapat disimpulkan bahwa terdapat pengaruh yang signifikan antara penggunaan media pembelajaran berbasis 
buku teks dengan hasil belajar. Nilai koefisein 0,893 menunjukan tingkat keeratan antara dua variabel tersebut sangat kuat. Besarnya koefisien korelasi penggunaan media pembelajaran berbasis buku teks dengan hasil belajar siswa adalah sebesar 0,893, sedangkan kooefisein determinasinya $79,7 \%$. Artinya bahwa pengaruh penggunaan media pembelajaran berbasis buku teks dengan hasil belajar siswa sangat signifikan. Dan hasil belajar siswa dipengaruhi oleh penggunaan media pembelajaran berbasis buku teks sebesar 79,7\%, sedangkan sisanya 20,3\% merupakan faktor lain, misalnya metode mengajar guru, ketekunan siswa atau kompetensi siswa yang lainnya.

Dari 50 orang sampel penelitian, jawaban responden mencapai rata-rata dari semua dimensi adalah 79,74 \% penggunaan media pembelajaran berbasis powerpoint dan $70,67 \%$ penggunaan media pembelajaran berbasis buku teks.

Berikut uraian skor penggunaan media pembelajaran :

Tabel1 Rangkuman skor Penggunaan media pembelajaran berbasis powerpoint

\begin{tabular}{|c|c|c|c|}
\hline No & Dimensi & Skor & Kategori \\
\hline 1 & Praktis,dapat digunakan untuk semua ukuran kelas. & $83,6 \%$ & SangatBaik \\
\hline 2 & $\begin{array}{l}\text { Memberikan kemungkinan tatap muka dan } \\
\text { Mengamati respon dari penerima pesan }\end{array}$ & $80 \%$ & SangatBaik \\
\hline 3 & Memberikan kemungkinan pada penerima pesan untuk mencatat & $86 \%$ & Baik \\
\hline 4 & $\begin{array}{l}\text { Memiliki variasi teknik penyajian dengan berbagai } \\
\text { Kombinasi warna atau animasi }\end{array}$ & $90 \%$ & Baik \\
\hline 5 & Dapat digunakan berulang-ulang. & $64,40 \%$ & Baik \\
\hline 6 & $\begin{array}{l}\text { Dapat dihentikan pada setiap sekuens belajar karena kontrol } \\
\text { Sepenuhnya pada komunikator }\end{array}$ & $83,50 \%$ & $\begin{array}{l}\text { Sangat } \\
\text { Baik }\end{array}$ \\
\hline 7 & $\begin{array}{l}\text { Lebih sehat dibandingkan menggunakan papan tulis dan } \\
\text { OHP }\end{array}$ & $83,10 \%$ & SangatBaik \\
\hline 8 & $\begin{array}{l}\text { Penyajian menarik karena ada permainan warna,huruf dan animasi, } \\
\text { baik animasi teks maupun animasi gambar atau foto }\end{array}$ & $80,8 \%$ & SangatBaik \\
\hline 9 & $\begin{array}{l}\text { Lebih merangsang anak untuk mengetahui lebih jauh informasi } \\
\text { tentang bahan ajar yang tersaji. }\end{array}$ & $83,6 \%$ & SangatBaik \\
\hline 10 & $\begin{array}{l}\text { Pesan informasi secara visual mudah dipahami peserta } \\
\text { didik }\end{array}$ & $82,4 \%$ & SangatBaik \\
\hline 11 & $\begin{array}{l}\text { Tenaga pendidik lebih efektif dalam menerangkan bahan ajar yang } \\
\text { sedang disajikan. }\end{array}$ & $80,6 \%$ & SangatBaik \\
\hline 12 & $\begin{array}{l}\text { Dapat disimpan dalam bentuk optik/magnetic (CD,Disket, Flashdisk) } \\
\text { sehingga praktis untuk dibawa kemana-mana. }\end{array}$ & $81,2 \%$ & SangatBaik \\
\hline
\end{tabular}




\begin{tabular}{|c|c|c|c|}
\hline 13 & $\begin{array}{l}\text { Mampu menampilkan objek-objek yang sebenarnya tidak } \\
\text { Ada secara fisik atau diistilahkan dengan imagery. }\end{array}$ & $82 \%$ & SangatBaik \\
\hline 14 & 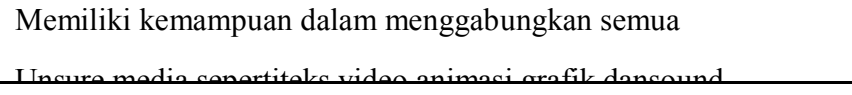 & $80,6 \%$ & SangatBaik \\
\hline & Menjadi satu kesatuan penyajian yang terintegrasi. & & \\
\hline 15 & $\begin{array}{l}\text { Memiliki kemampuan mengakomodasi pesertadidik } \\
\text { Sesuai dengan modalitas belajarnya,terutama bagi mereka yang } \\
\text { memiliki tipevisual,auditif,kinestetika tau yang lainnya }\end{array}$ & $74,1 \%$ & Baik \\
\hline 16 & $\begin{array}{l}\text { Mampu mengembangkan materi pembelajaran terutama } \\
\text { membacadan mendengarkan secara mudah. }\end{array}$ & $78 \%$ & Baik \\
\hline 17 & $\begin{array}{l}\text { Memperjelas penyampaian pesan agar tidak terlalu bersifat } \\
\text { verbalitas (dalam bentuk kata-kata tertulis atau lisan belaka). }\end{array}$ & $75,6 \%$ & Baik \\
\hline 18 & Mengatasi keterbatasan ruang, waktu dan daya indera. & $72,3 \%$ & Baik \\
\hline 19 & $\begin{array}{l}\text { Penggunaan secara tepat dan variasi dapat mengatasi sikap } \\
\text { Pasif anak didik. }\end{array}$ & $68,4 \%$ & Baik \\
\hline 20 & $\begin{array}{l}\text { Untuk mengoperasikan microsoftpowerpoint, sesorang } \\
\text { Membutuhkan keterampilan khusus }\end{array}$ & $83,2 \%$ & SangatBaik \\
\hline 21 & $\begin{array}{l}\text { Microsoftpowerpoint harus dijalankan dengan komputer } \\
\text { Yang mana membutuhkan biaya yang cukup tinggi untuk } \\
\text { mendapatkannya }\end{array}$ & $81,2 \%$ & SangatBaik \\
\hline & Rata-rata & $79,74 \%$ & Baik \\
\hline
\end{tabular}

Berdasarkan tabel 1, dapat diketahui rata-rata skor dari setiap dimensi penggunaan media pembelajaran berbasis powerpoint sebesar $79,74 \%$, pada kategori baik artinya indikator-indikator yang secara teoritis telah di bahas pada bab II yang berkaitan dengan penggunaan media pembelajaran berbasis powerpoint telah terpenuhi dengan baik. Beberapa faktor yang mendukung penggunaan media pembelajaran berbasis powerpoint di MIN 2 Jember berkategori baik adalah:

a. Guru telah menyajikan materi pelajaran IPA menggunakan media powerpoint melalui laptop dan disambungkan pada LCD.

b. Guru telah mendesain materi pelajaran IPA yang menarik minat siswa dengan cara menggabungkan teks, gambar dan video serta mengkombinasikan warna.

c. Media powerpoint bersifat praktis bisa disimpan dalam flashdisk dan bisa digunakan berulang-ulang. 
2. Penggunaan media pembelajaran berbasis power point.

Tabel2 Rangkumanskor PenggunaanmediapembelajaranberbasisBukuTeks

\begin{tabular}{|c|c|c|c|}
\hline No & Dimensi & Skor & Kategori \\
\hline 1 & Sebagai bahan evaluasi & $78 \%$ & Baik \\
\hline 2 & $\begin{array}{l}\text { Sebagai alat bantu pendidik dalam melaksanakan } \\
\text { Kurikulum }\end{array}$ & $73,4 \%$ & Baik \\
\hline 3 & $\begin{array}{l}\text { Menyediakan materi pembelajaran yang menarik } \\
\text { gi peserta didik }\end{array}$ & $74,6 \%$ & Baik \\
\hline 4 & $\begin{array}{l}\text { Membantu pendidik dalam melaksanakan } \\
\text { Kurikulum karena disunberdasarkan kurikulum yang } \\
\text { berlaku. }\end{array}$ & $73,2 \%$ & Baik \\
\hline 5 & $\begin{array}{l}\text { Menjadi pegangan guru dalam menentukan } \\
\text { Metode pengajaran }\end{array}$ & $74 \%$ & Baik \\
\hline
\end{tabular}

\begin{tabular}{|c|l|c|c|}
\hline 6 & $\begin{array}{l}\text { Memberikan pengetahuan bagi peserta didik } \\
\text { Maupun pendidik }\end{array}$ & $66,4 \%$ & Baik \\
\hline 7 & $\begin{array}{l}\text { Secara formal,buku teks pelajaran diterbitkan } \\
\text { Oleh penerbit tertentu dan memilki ISBN }\end{array}$ & Baik \\
\hline 8 & $\begin{array}{l}\text { Bermisioptimalisasi pengembangan pengetahuan } \\
\text { Deklaratif dan prosedural }\end{array}$ & $76,4 \%$ \\
\hline 9 & $\begin{array}{l}\text { Berorientasi pada keterampilan proses dengan } \\
\text { masyarakat serta demonstrasi dan eksperimen }\end{array}$ & Baik \\
\hline 10 & $\begin{array}{l}\text { Memberigambaransecarajelastentang } \\
\text { keterpaduanatauketerkaitannyadengandisiplin }\end{array}$ & $68,3 \%$ & Baik \\
\hline
\end{tabular}


Berdasarkan tabel 2, dapat diketahui rata-rata skor dari setiap dimensi Penggunaan media pembelajaran berbasis Buku Teks sebesar 70,67\%, pada kategori baik artinya indikator-indikator yang secara teoritis berkaitan dengan Penggunaan media pembelajaran berbasis Buku Teks telah terpenuhi dengan baik.

3. Hasil Belajar siswa kelas VI MIN 2 Jember Mata Pelajaran IPA Materi Tata Surya

Tabel3Rangkumanskor hasilbelajarsiswa

\begin{tabular}{|c|l|c|c|}
\hline No & \multicolumn{1}{|c|}{ Dimensi } & Skor & Kategori \\
\hline 1 & Kompetensi Mengingat & $75,64 \%$ & Baik \\
\hline 2 & Kompetensi Memahami & $76,20 \%$ & Baik \\
\hline 3 & Kompetensi Menerapkan & $76 \%$ & Baik \\
\hline 4 & Kompetensi menganalisis & $72,5 \%$ & Baik \\
\hline 5 & Kompetensi Mengevaluasi & $62,04 \%$ & Baik \\
\hline 6 & Kompetensi Mencipta & $70,8 \%$ & Baik \\
\hline \multicolumn{2}{|r|}{ Rata-rata } & $72,19 \%$ & Baik \\
\hline
\end{tabular}

Berdasarkan tabel 3, dapat diketahui rata-rata skor dari setiap dimensi hasil belajar siswa sebesar $72,19 \%$, pada kategori baik artinya indikator-indikator yang secara teoritis telah berkaitan dengan hasil belajar telah dimiliki oleh siswa MIN 2 Jember dengan baik.

Berdasarkan hasil pengujian dan uraian di atas, terdapat pengaruh yang signifikan antara penggunaan media pembelajaran berbasis powerpoint dan media pembelajaran berbasis buku teks dengan hasil belajar siswa sehingga peningkatan penggunaan media pembelajaran mampu meningkatkan hasil belajar siswa MIN 2 Jember Mata Pelajaran IPA materi Tata surya.

\section{PEMBAHASAN}

Dari uraian hasil penelitian, media pembelajaran sebagai salah satu komponen pendukung untuk mencapai tujuan pembelajaran yang sangat berperan dalam meningkatkan kualitas pendidikan, seperti diungkapkan Azhar Arsyad (2011:7) menyatakan bahwa media pembelajaran merupakan alat bantu pada proses belajar mengajar baik didalam ruang maupun diluar ruangan yang ditekankan pada visual dan video. Sedangkan menurut Syaiful Bahri Djamarah dan Azwan Zain (2010:121) mengungkapkan bahwa media pembelajaran adalah alat bantu apa saja yang dapat dijadikan sebagai penyalur pesan agar tercapai tujuan pembelajaran.

Media pembelajaran merupakan salah faktor penting dalam meningkatkan kualitas pendidikan, sehingga media pembelajaran perlu dimanfaatkan oleh guru dalam pembelajaran. Hasil belajar siswa yang optimal merupakan tujuan dari proses 
pembelajaran, oleh karena itu hasil belajar siswa perlu ditingkatkan, salah satunya dengan memanfaatkan media pembelajaran berbasis powerpoint dan buku teks.

Penggunaan media pembelajaran berbasis powerpoint dan media pembelajaran berbasis buku teks merupakan faktor eksternal yang dapat mempengaruhi hasil belajar siswa dalam proses pembelajaran. Hasil penelitian ini juga menunjukan terdapat pengaruh yang signifikan antara penggunaan media pembelajaran berbasis powerpoint terhadap hasil belajar siswa. Nilai koefisien korelasi sebesar 0,863 menunjukan tingkat keeratan antara dua variabel tersebut adalah sangat kuat. Dengan demikian, jika penggunaan media pembelajaran berbasis powerpoint baik dan meningkat, maka hasil belajar siswa akan meningkat dan berhasil dengan baik. Dari hasil perhitungan dengan analisis regresi $\operatorname{linier}^{\wedge}$

sederhana didapatkan persamaan:

$Y=20,125+0,863 \mathrm{X}_{1}$, artinya bahwa kualitas

penggunaan media pembelajaran berbasis powerpoint ditingkatkan sampai 165 (5skor tertinggi x 33 butir pernyataan), maka kinerja guru akan menjadi 162,52. Dengan demikian penggunaan media pembelajaran berbasis powerpoint memiliki pengaruh terhadap hasil belajar siswa.

Siswa sebagai sumber daya pendidikan memerlukan pertumbuhan dan perkembangan yang baik, sebagai salah satu komponen pendidikan, siswa memerlukan penggunaan media pembelajaran berbasis powerpoint dan media pembelajaran berbasis buku teks. Guru sebagai motivator/pembimbing, tentu saja harus dapat memanfaatkan media pembelajaran guna mencapai tujuan pembelajaran.

Dalam penelitian ini, penggunaan media pembelajaran berbasis buku teks telah diteliti seberapa besar pengaruhnya dengan hasil belajar siswa, hasilnya koefisien korelasi adalah 0,983. Nilai koefisien korelasi sebesar 0,983 menunjukan tingkat keeratan antara dua variabel tersebut adalah sangat kuat.

Dengan demikian, jika penggunaan media pembelajaran berbasis buku teks baik dan meningkat, maka hasil belajar siswa akan meningkat dan berhasil dengan baik. Dari hasil perhitungan dengan analisis regresi linier sederhana didapatkan persamaan : $Y=15,822+0,983 \mathrm{X}_{2}$, artinya bahwa kualitas 
penggunaan media pembelajaran berbasis buku teks ditingkatkan sampai 75 (5skor tertinggi x 15 butir pernyataan), maka hasil belajar siswa akan menjadi 82,797. Maka penggunaan media pembelajaran berbasis buku teks memiliki pengaruh terhadap hasil belajar siswa mata pelajaran IPA materi tata surya

Dapat dipahami bahwa ada pengaruh antara penggunaan media pembelajaran berbasis powerpoint dan media pembelajaran berbasis buku teks dengan hasil belajar siswa. Secara bersamaan penggunaan media pembelajaran berbasis powerpoint, media pembelajaran berbasis buku teks dan hasil belajar siswa memiliki koefisien korelasi (R) 0,934, menunjukkan tingkat keeratan antara ketiga variabel tersebut sangat kuat, sedangkan besarnya pengaruh kedua media pembelajaran terhadap hasil belajar siswa adalah sebesar $87,23 \%$. Pengaruhnya cukup besar dan signifikan Sedangkan persamaan regresinya adalah $Y=8,401+0,430 \mathrm{X}_{1}+0,562 \mathrm{X}_{2}$. Berdasarkan persamaan tersebut ditemukan harga $\mathrm{a}=8,401, \mathrm{~b} 1=0,430$ dan $\mathrm{b}_{2}=0,562$. Apabila penggunaan media pembelajaran berbasis powerpoint dan media pembelajaran berbasis buku teks dioptimalkan $\left(\mathrm{X}_{1}=165\right.$ dan $\left.\mathrm{X}_{2}=75\right)$, maka hasil belajar siswa menjadi $Y=8,401+$ $0,430(165)+0,562(75)=121,501$. Artinya dengan penggunaan media pembelajaran berbasis powerpoint dan media pembelajaran berbasis buku teks yang baik, maka hasil belajar siswa akan mencapai yang tinggi/optimal.

\section{KESIMPULAN DAN SARAN}

\section{a. Kesimpulan}

Penggunaan media pembelajaran berbasis power point, di MIN 2 Jember, berdasarkan hasil penelitian memiliki kecenderungan tergolong pada kategori baik dalam meningkatkan hasil belajar siswa. Hal ini dapat dilihat dari hasil penelitian penggunaan media pembelajaran berbasis power point yang terdiri semua dimensi memiliki rata-rata sebesar 79,74\%. Sedangkan untuk Penggunaan media pembelajaran berbasis buku teks, untuk semua dimensi memiliki rata-rata sebesar70,67\%.

Sebagian besar siswa dapat mencapai hasil belajar dari semua level kemampuan, yaitu untuk dimensi kompetensi mengingat sebesar 75,64\% (kategori baik), dimensi kompetensi memahami sebesar 76,20\% (kategori baik), dimensi kompetensi menerapkan sebesar 76\% (kategori baik), dimensi kompetensi menganalisis sebesar 72,5\% (kategori baik), dimensi kompetensi mengevaluasi sebesar 62,04\% (kategori baik), sedangkan untuk dimensi kompetensi 
mencipta sebesar 70,8\% (kategori baik). Dengan demikian penggunaan media pembelajaran berbasis powerpoint dan media pembelajaran berbasis buku teks yang baik, maka guru akan dengan mudah membimbing dan mengarahkan siswa guna mencapai hasil belajar yang tinggi/ optimal.

\section{b. Saran - saran}

Berdasarkan hasil penelitian ini, beberapa saran yang perlu disampaikansebagai berikut :

1. Kepala sekolah harus memfasilitasi sarana pendukung media pembelajaran guna tercapainya tujuan pembelajaran

2. Guru IPA hendaknya selalu menggunakan media pembelajaran khususnya berbasis powerpoint dan berbasis buku teks

3. Guru IPA hendaknya selalu mendesain media pembelajaran ketika membuat perencanaan pembelajaran.

4. Guru IPA harus berusaha meningkatkan hasil belajar siswa secara optimal melalui penggunaan media pembelajaran, sehingga mampu meningkatkan mutu proses pembelajaran dan mutu pendidikan

5. Peneliti berikutnya, dapat melakukan penelitian dengan mengembangkan media pembelajaran yang lebih up to date sehingga lebih memotivasi belajar siswa guna mencapai hasil belajar yang lebih optimal.

\section{PUSTAKA ACUAN}

Abiodun, et al (2015). The Relevance Of Multi Media Skills In Teaching And Learning Of Scientific Concepts In Secondary Schools In Lagos State, Nigeria. Journal of Education and Practice. 6(15)

Alaa Sadik \& Khadeja Badr (2012). The effectiveness of classroom-based supplementary video presentations in supporting emergent literacy Development in early childhood education. Journal on Educational Psychology.5(3).

Achmad Rifa'I dan Chatarina Tri Anni.(2009), Psikologi pendidikan Semarang Unnes Press.

Achmad Rifa'I. (2009), Psikologi pendidikan. Semarang Unnes Press.

Ahmad Tafsir.(2003). Ilmu Pendidikan dalam Perspektif Islam . Bandung: remaja rosda karya.

Alice, Crow. \& Lester D, Crow. (1992). Educational Psychology. New Jersey: Littlefeld Adams and Co.

Altbach, P.G. (1991). Textbooks in American Society: Politics, Policy, and Pedagogy. Buffalo: SUNY Press. 
Arief S Sadiman, dkk. (2007). Media Pendidikan. Jakarta: PT. Raja Grafindo

Persada.

Arikunto, Suharsimi. (2006). Prosedur Penelitian Suatu Pendekatan Praktik.

Jakarta: Rineka Cipta.

Arikunto. (2010). Prosedur Penelitian suatu Pendekatan Praktik. Jakarta: Rineka

Cipta.

Arsyad, Azhar. (2011). Media Pembelajaran. Jakarta: Rajawali Press.

Clifford T. Morgan. (2007). Introduction to Psychology, Sixth Edition. New

York: MC Graw HillInternational Book Company.

Creswell, J. W. (2010). Research design pendekatan kualitatif, kuantitatif, dan mixed. Yogyakarta: Pustaka Pelajar

Daryanto. (2010). Media Pembelajaran. Yogyakarta: Gava Media

Depdiknas.(2003).Undang-undang RI No.20 tahun 2003.tentang sistem pendidikan nasional.

Depdiknas .(2006).Permendiknas No 22 Tahun 2006 Tentang Standar Isi. Jakarta

: Depdiknas.

Depdiknas. (2006). Kurikulum Tingkat satuan Pendidikan (KTSP) untuk Sekolah

Dasar/MI. Jakarta:Terbitan Depdiknas.

Djamaludin, Ancok, (1989), "Validitas dan Reliabilitas Instrument Penelitian", dalam Masri Singarimbun dan Sofian Efendi, “Metode Penelitian Survey”, Jakarta, LP3ES.

Hamidi. (2004). Metode Penelitian Kualitatif: Aplikasi Praktis Pembuatan

Proposal dan Laporan Penelitian. Malang: UMM Press.

Handayani, Ani. (2013). Peningkatan Sikap Peduli Lingkungan Melalui Implementasi Pendekatan Sains Teknologi Masyarakat (STM) dalam Pembelajaran IPA Kelas IV.1 SDN Keputran "A". Yogyakarta: Universitas Negeri Yogyakarta.

https://dosenit.com/software/microsoft/kelebihan-dan-kekurangan power-point

(diakses 23 Desember 2018)

http://pamongsakaba.wordpress.com/2009/09/29/pemanfaatan-microsoft-power- point-untuk-mediapembelajaran/ . (Akses 14 April 2018)

Khairudin. (2007). Kurikulum tingkat Satuan pendidikan. Jogjakarta: Nuansa

Aksara.

Khoo, E., Hight, C., Cowie,B., Torrens. R., \& Ferrarelli, L. (2014). Software literacy and student learning in the tertiary environment: PowerPoint and beyond. Journal of Open, Flexible and Distance Learning, 18(1), [30-

45]

Muhibbin Syah. (2003). Psikologi Belajar. Jakarta: PT. Raja Grafindo Persada. Mulyasa, E (2005). Menjadi

Guru Profesional : Menciptakan Pembelajaran

Kreatif dan Menyenangkan. Bandung: Remaja Rosdakarya. Bandung

Munadi, Yudhi. (2010). Media Pembelajaran "Sebuah Pendekatan Baru". 
Jakarta: Gaung Persada Press.

Muslich, Masnur. (2010). Textbookwriting: Dasar-dasarpemahaman, penulisan, dan pemakaian buku teks. Jogjakarta: Ar-Ruzz Media.

Nana Sudjana. (2009). Penilaian Hasil Proses Belajar Mengajar. Bandung: PT Remaja Rosdakarya.

Nana Syaodih Sukmadinata. (2005). Metode Penelitian Pendidikan. Bandung: Remaja Rosda Karya.

Priyanto, Dwi. (2008). Mandiri Belajar SPSS. Yogyakarta: MediaKom. Purwanto, Ngalim. (2004). Psikologi Pendidikan. Bandung: Remaja

Richard, JC \& Rodgers T. (2002). Approac hes and Methods in Language Teaching. Cambridge: Cambridge University Press.

Riyana, Ilyasih. (2008). Pemanfaatan OHP dan Presentasi dalam Pembelajaran.

Jakarta: Cipta Agung. Rosdakarya.

Sadiman, Arief S. dkk. (2008). Media Pendidikan Pengertian, Pengembangan, dan Pemanfaatannya. Jakarta: Pustekkom Dikbud dan PT.Raja Grafindo Persada.

Saifuddin Azwar. (2008). Tes Prestasi dan Pengembangan Pengukuran Prestasi

Belajar. Yogyakarta: Pustaka Pelajar.

Sarwono, Jonathan (2006). Analisis Data Penelitian Menggunakan SPSS, Yogyakarta: Andi,

Slameto. (2010). Belajar dan Faktor-faktor yang Mempengaruhinya. Jakarta: Rineka Sudjana, (2009).

Penilaian Hasil Proses Belajar Mengajar. Bandung: Rosdikarya.

Sugiyono, (2013), Metodelogi Penelitian Kuantitatif, Kualitatif Dan R\&D. (Bandung: ALFABETA)

Sugiyono. (2009). Metode Penelitian Kuantitatif. Bandung: Alfabeta.

Sumadi Suryabrata. (2003) Psikologi Pendidikan. Jakarta: Raja Grafindo

Persada.

Susilana, Rudi, (2007). Media Pembelajaran. Bandung: CV. Wacana Prima. Syaiful Bahri Djamarah. (2002).

Psikologi Belajar. Jakarta: PT Rineka Cipta. Tomlinson,B. \& Masuhara (2004). Developing Language Course Materials.

Singapore: RELC Portfolio Series.

WS. Winkel. (2003). Psychologi Pendidikan. Jakarta: Gramedia. 